cakes, and good results were obtained on two shipments of frozen fish, using new freezing-mixtures in railway refrigerator cars. Progress was made in the production of glycerol by fermentation of beet molasses, and papers of the glassine or parchment type were obtained from several cereal straws. Construction of the Prairie Regional Laboratory advanced during 1948, and three laboratories began operating, for bacteriology, mycology and fermentation chemistry; a fourth laboratory, for antibiotics and enzyme chemistry, was due to be staffed.

The Division of Building Research concentrated attention on questions of building practice in relation to house construction, including studies of the construction of houses built without basements but resting on flat concrete slabs and of cavity-wall construction. In the Division of Chemistry, photochemical and other kinetic investigations on acetone, acetaldehyde, ethylene oxide and hydrocarbons yielded information on the reactions of the free radicals involved, and radioactive carbon was used to label functional groups so as to follow their course in photochemical reactions. The compressibility of helium was measured with a high degree of accuracy in the range $0-600^{\circ} \mathrm{C}$., and work continued on the infra-red absorption spectra of complex organic compounds, including deuterium-enriched compounds, and on the acid dyeing of wool. In addition to its service functions, the Applied Chemistry Branch carried out numerous investigations in such fields as textiles, rubber, protective coatings and organic synthesis, mainly directed towards the application of new scientific knowledge in chemical industry.

Basic investigations by the Division of Mechanical Engineering, the aeronautical laboratories of which provide research, development and testing facilities for the Canadian aviation industry and also function as the research organisation of the Royal Canadian Air Force, included further work on the control and stability of tailless aircraft, the behaviour of turbines under low-temperature conditions and the icing of turbines. The engine laboratory was in the process of being modified to accommodate jet and propeller-jet units, and the facilities of the model-testing basin were extended by the provision of self-propulsion equipment. Further work was done on the model of the Fraser River for the Department of Public Works, and problems in connexion with the use of fuels and lubricants at low temperatures continued to be a major activity. During the year 1949-50 one hundred and eleven projects were scheduled for support by grants-in-aid under the Division of Medical Research, including fundamental research on such subjects as physiology and biochemistry of muscular activity; cellular development; growth destruction and regeneration; the physiology and biochemistry of nervous and special sense activity; mechanisms of secretion; metabolic studies, including the role of vitamins; studies on blood constituents, including the cells; enzymes; lipids and clothing agents.

In the Division of Physics, progress was made in planning and building the laboratory for a spectroscopy group, and an investigation was started on the influence of the magnetic field of the earth on cosmic rays. A new type of accelerator which produces 4.5 $\mathrm{MeV}$. electrons was substantially completed, some of the equipment for geophysical prospecting was modified for measuring the depth of glaciers, and the factors affecting the resolving power in a print were examined by a projection. A study was also being made of methods of applying Shoran radar technique in measuring the distance between two fixed points on the ground with an accuracy sufficient for geodetic purposes, and in determining the position of an aircraft, engaged in taking photographs, at intervals along a flight line. A fully automatic ionospheric recorder was being developed for the study of radiowave propagation, and a simplified, low-cost marine radar set developed for the use of Canadian shipping was in the process of being produced by a Canadian manufacturer. Trials were conducted to obtain a comparison on the three- and ten-centimetre bands of the interference to radar equipment caused by rain and snowstorms.

\section{LIBRARY STATISTICS IN THE UNITED STATES}

TNDER the title "Statistics of Libraries in Institutions of Higher Education, 1946-47", the Research and Statistical Service of the Office of Education has issued as Chapter 6 of the Biennial Survey of Education in the United States, 1946-48, a summary of the distribution and status of library service in higher educational institutions in the United States, and some interpretation of the detailed statisties tabulated*. The pamphlet was prepared by W. O. Mishoff and E. M. Foster, and is based on library reports from 1,345 institutions, or $79 \cdot 1$ per cent of such institutions in the United States, and including 680 of the 779 colleges and universities and 175 of the 265 professional and technological schools.

Analysing the returns, the report points out that colleges and universities added an average of $2 \cdot 0$ books per student to their stocks, professionsl and technological schools adding 1.8 books. Of 1,311 institutions reporting this item, the number that, made additions during the year fell into the following ranges of number of volumes: less than 1,000, 591; $1,000-4,999,594 ; 5,000-24,999,107$; and more than $25,000,19$ volumes. Moreover, while 26.5 per cent of the universities and colleges reporting added fewer than a thousand volumes, 1 per cent acquired fifty thousand or more volumes, and 0.6 per cent of the professional and technological schools added from ten to fifteen thousand volumes. Of the total holdings, colleges and universities accounted for 83.3 per cent and professional and technological schools for $6 \cdot 7$ per cent, eleven of the former owning one million or more volumes. Inter-library loans totalled 101,866 volumes, and 93,093 volumes were borrowed from other libraries by those of higher educational institutions.

Only 161 libraries were open for eighty hours or more per week; but 555 were open for 60-79 hours and 490 for $40-59$ hours. The total operating expenditure exceeded 34.6 million dollars or almost double that of 1939-40, but expenditure per student only increased from $15 \cdot 3$ to 18 dollars ; in colleges and universities it averaged 39.2 dollars, and in professional and technological schools $15 \cdot 7$ dollars per student. Of colleges and universities, nineteen spent 300,000 dollars on more library operations; but thirty-eight spent less than 3,000 dollars. Library services employed 8,511 full- and 2,106 part-time workers, and, while nine colleges or university libraries employed more than a hundred library workers, 121 employed only one.

* Federal Security Agency : Offlce of Education. Biennial Survey of Education in the United States, 1946-48. Chapter 6: Statistics of Libraries in Institutions of Higher Education, 1946-47. Prepared by Willard O. Mishoff and Fmery M. Foster. Pp. $v+49$. (Washington,
D.C. : Government Printing Office, 1949.) 20 cents. 